OPEN ACCESS

Edited by:

Alain Jacquet,

Chulalongkorn University, Thailand

Reviewed by:

Richard E. Goodman

University of Nebraska-Lincoln,

United States

Young-Min Ye,

Ajou University, South Korea

*Correspondence:

Kyoung Yong Jeong

jeongky@yuhs.ac

Jung-Won Park

parkjw@yuhs.ac

Specialty section:

This article was submitted to

Allergens,

a section of the journal

Frontiers in Allergy

Received: 12 January 2021

Accepted: 17 February 2021

Published: 05 March 2021

Citation:

Jeong KY and Park J-W (2021)

Allergens of Regional Importance in Korea. Front. Allergy 2:652275. doi: 10.3389/falgy.2021.652275

\section{Allergens of Regional Importance in Korea}

\author{
Kyoung Yong Jeong* and Jung-Won Park* \\ Department of Internal Medicine, Institute of Allergy, Yonsei University College of Medicine, Seoul, South Korea
}

Allergen repertoire should reflect the region's climate, flora, and dining culture to allow for a better diagnosis. In Korea, tree pollens of oak and birch in the spring in conjunction with weed pollens of mugwort, ragweed, and Japanese hop are the main causes of seasonal allergic rhinitis. More specifically, the sawtooth oak in Korea and the Japanese hop in East Asia make a difference from western countries. Among food allergens, the sensitization to silkworm pupa and buckwheat is also common in Korean patients. Honey bee venom due to apitherapy in traditional medicine and Asian needle ant, Pachycondyla chinensis, are important causes of anaphylaxis in Korea. Climate change, frequent overseas traveling, and international product exchanges make situations more complicated. Ragweed, for example, was not native to Korea, but invaded the country in the early 1950s. Recently, Japanese hop and Asian needle ants have been recognized as important invasive ecosystem disturbing species in western countries. However, the molecular properties of the component allergens from these unique culprit allergens have been poorly characterized. The present review summarizes the molecular studies on the allergens of regional importance in Korea.

Keywords: native species, invasive species, allergen repertoire, allergen, allergy diagnosis

\section{INTRODUCTION}

Sensitization to an allergen should reflect the exposure from the allergen in the environment. The environment includes climate, which determines fauna and flora, and cultural differences including dining. Different plant and animal species produce different allergen molecules. Some allergens, especially for molecules called pan-allergens, share highly conserved IgE epitopes. However, several differences exist even between allergens that belong to the same protein family. The same species can also produce different isoallergens or isoforms. Different food processing, which reflects cultural aspects, also affects the integrity and modifies the allergenic properties of foodstuffs. In traditional oriental medicine, various local herbs and animal products remain actively utilized for the medicine. Apitherapy (honey bee venom therapy) is a good example of the differences.

These differences in culprit allergens can influence the efficacy of immunotherapy as well as diagnostic sensitivity. However, diagnosis and immunotherapy in Asia rely on the allergen extracts produced from western countries. Some allergens of regional importance are not yet commercially available, and allergy diagnoses depends on cross-reactivity with the extracts from similar species. Furthermore, edible insect allergens should be taken into account since some studies are being performed to develop future diet and animal feed without sufficient investigations on allergic side effects.

This review summarizes the important species in Korea and their cross-reactivity with the representative species. Allergen characteristics will also be discussed if molecular studies have been completed. 


\section{INHALANT ALLERGENS OF REGIONAL IMPORTANCE}

The 10 most common inhalant allergens (D. farinae, $D$. pteronyssinus, Tyrophagus putrescentiae, cat epithelium, birch, mugwort, alder, hazel, beech, and oak) account for $90 \%$ of inhalant allergen sensitization in a retrospective analysis of skin tests (1). However, many of the positives are not of primary sensitization, but as a result of cross-reactions. A significant increase of skin reactivity over 30 years in Korea was observed with oak (4.7 to $14.4 \%$ ), birch (7.1 to $13.6 \%$ ), alder (6.3 to $13.4 \%$ ), and pine (2.9 to $14.3 \%$ ) in the 2010 s compared to the 1990 s (2). Skin reactivity to grass (13.9 to $20.3 \%$ ) and weed (27.0 to $40.9 \%$ ) pollens increased, while no differences were observed with house dust mites (55.2 to $55.6 \%$ ) during the same period.

\section{Tree Pollen}

Trees in the spring and weeds in autumn are is the most important causes of pollinosis in Korea. The pollen concentrations of oak in the spring and Japanese hop during the autumn season were the most common in the Korean atmosphere (3). Currently, no pollen extracts from oak and birch native to Korea are commercially available (Table 1). Siberian silver birch, instead of common silver birch, is native to Korea. However, birch trees remain uncommon. The most abundant oak species in Korea is the Mongolian oak. Que m 1 from Mongolian oak exhibited better diagnostic value than Bet v 1 (4). However, most Mongolian oaks are found in the mountains with sawtooth oak being common near villages. Moreover, sawtooth oak pollen extracts exhibited stronger allergenic activity compared to Mongolian oak pollen extract (5). Recently, the allergenicity of Que ac 1 from sawtooth oak was investigated (Jeong et al. manuscript in submission). Que ac 1 was shown to be highly polymorphic. The IgE reactivity of recombinant Que ac 1 was more potent than Bet v 1 in Korean oak pollinosis patients. However, no significant differences were displayed in mediator release assays with rat basophilic leukemia cells.

\section{Weed Pollen Japanese Hop}

Autumn pollinosis in Korea is elicited by weed species like ragweed, mugwort, and Japanese hop. Grass causes summer pollinosis, but is rare in Korea. Japanese hop is of particular interest for its high atmospheric concentration in East Asia and recent invasion into Western countries. Interestingly, it exhibited no essential cross-reactivity with a common hop, a closely related species, nor mugwort or ragweed (6-8). However, the molecular details of its allergens have yet to be characterized. A $10 \mathrm{kDa}$ component is known to be a major allergen (7) even though it has not been cloned. Recombinant proteins of profilin, pathogenesis-related 1, polygalacturonase, and pectin methyl esterase, homologous to pollen allergens from Japanese hop, were recognized with 3.4 to $13.8 \%$ of IgE antibodies from the patients $(9,10)$.

\section{Mugwort}

Up to 500 different mugwort species have been described worldwide (11). In Korea, 26 mugwort species have been recorded with Artemisia princeps being the most prevalent (12). Fortunately, a high sequence identity of three groups of allergens (Art v 1, 2, and 3) from different species and almost equivalent IgE binding capacity of these allergens were reported, allowing diagnosis and immunotherapy with commercialized mugwort extracts $(13,14)$.

\section{House Dust Mites and Spider Mites}

House dust mites are the most frequent cause of allergic diseases (15). Cross-reactivity between house dust mites and storage mites often lead to false-positive reactions to storage mites $(16,17)$. Polymorphisms of the major allergens from Korean house dust mite isolates (18) were investigated, and sensitization patterns to component allergens were also examined $(19,20)$. Mite allergic patients suffering from respiratory symptoms were more likely to be sensitized only to Der f 1 and Der f 2 allergens. However, patients suffering from cutaneous symptoms were shown to be sensitized to minor allergens, Der f 11, Der f 13, Der f 14, Der f 32, and Der f Alt a 10 (20). Notably, further studies on IgE reactivity to some of component allergens such as Der p 23, known as a major allergen from Western countries (21), are to be done. Recombinant Der f 23 was recognized by $42.8 \%$ of serum IgE from patients, while Der f 2 was recognized by $96.4 \%$ (22).

More interestingly, a high sensitization rate to spider mites was described (23). However, the molecular characterization of its allergens has not completed. Cross-reactivity between spider mites and house dust mites should also be performed to verify whether primary sensitization to spider mites is common.

\section{Midges}

It is possible that allergic reactions to swarming insect species such as mayflies, stoneflies, and midges can occur. Hemoglobinlike proteins, which help with oxygen uptake in the water, have long been described as the major allergen from the blood worm, chironomid larvae (24). However, these molecules are not found in the adult stage. Tropomyosin, a highly cross-reactive invertebrate pan-allergen, was described as a major allergen from the adult midge of a dominant species (25). A $42 \mathrm{kDa}$ protein was recently identified as a novel allergen from Cricotopus bicintus, a hemoglobin-free midge (26).

\section{Companion Animals}

Certain dog breeds are being marketed as being hypoallergenic without reliable scientific evidence (27), and some recent studies suggest no evidence of hypoallergenic dog breeds (27, 28). However, the possible different allergenicity of different dog breeds has been described (29-31). Therefore, more investigations are needed on small-sized dog breeds such as the Maltese, Pomeranian, and Poodle, which are popular in Korea. Genetic differences and living environments, including housing situation, diet, and washing habits, may influence the production and accumulation of allergenic substances. 
TABLE 1 | Comparison of native and imported commercial plant species for clinical use.

\begin{tabular}{|c|c|c|c|c|}
\hline \multirow[t]{2}{*}{ Plant } & \multicolumn{2}{|c|}{ Imported species for clinical use } & \multicolumn{2}{|c|}{ Native species } \\
\hline & Scientific name & Common name & Scientific name & Common name \\
\hline Birch & Betula pendula & Common silver birch & Betula platyphylla var. japonica & Siberian/Japanese silver birch \\
\hline \multirow[t]{5}{*}{ Oak } & Quercus alba & White oak & Q. mongolica & Mongolian oak \\
\hline & & & Q. acutissima & Sawtooth oak \\
\hline & & & Q. dentata & Japanese emperor/Daimyo oak \\
\hline & & & Q. aliena & Oriental white oak \\
\hline & & & Q. variabilis & Chinese cork oak \\
\hline Ragweed & Ambrosia artemisiifolia & Common/short ragweed & Ambrosia artemisiifolia & Common/short ragweed \\
\hline Mugwort & Artemisia vulgaris & Mugwort & Artemisa princeps & Korean mugwort \\
\hline Hop & Humulus lupulus & Common hop & Humulus japonicus & Japanese hop \\
\hline
\end{tabular}

\section{FOOD ALLERGENS OF REGIONAL IMPORTANCE}

Egg and milk are the most common causes of allergic diseases in Korean children (32), while fruits associated with pollen food allergy syndromes, wheat, and crustaceans are the most frequent causative allergens in Korean adult subjects $(33,34)$. Interestingly, sensitization to silkworm pupa was most common (25.4\%), but the majority of the silkworm pupa-sensitized subjects were asymptomatic to exposure.

\section{Fruits and Food Allergy}

Foods $(84.8 \%)$ are the most common cause of anaphylaxis, followed by drugs (7.2\%) in Korean children (35), while drugs (58.3\%) are the most common cause, followed by food $(28.3 \%)$ in adults. The major causative foods of immediate-type food allergy were cow's milk (28.1\%), hen's eggs (27.6\%), wheat (7.9\%), walnut $(7.3 \%)$, peanut $(5.3 \%)$, buckwheat (1.9\%), and shrimps (1.9\%) in children (36). Among the Korean PFAS patients, $8.9 \%$ suffered from anaphylaxis (37). The most common cause of anaphylaxis in PFAS was peanut $(33.3 \%)$, followed by apple (33.3\%), walnut $(22.2 \%)$, pine nut $(18.5 \%)$, peach $(14.8 \%)$, and ginseng (14.8\%) (38). Foods associated with PFAS are peach (48.5\%), apple (46.7\%), kiwi (30.4\%), peanut (17.4\%), plum (16.3\%), chestnut $(14.8 \%)$, pineapple (13.7\%), walnut $(14.1 \%)$, Korean melon (12.6\%), tomato (11.9\%), melon (11.5\%), apricot $(10.7 \%)$. Interestingly, Korean foods such as taro (8.9\%), ginseng (8.2\%), sesame leaf (4.4\%), bellflower root (4.4\%), crown daisy (3.0\%), deodeok (3.3\%), kudzu root (3.0\%) and lotus root $(2.6 \%)$ also cause PFAS (36). The studies on sensitization pattern to component allergens can provide better picture of crossreactivity and peculiarity of Korean foods. However, molecular characterizations of major allergens from Korean foods have not been done.

\section{Buckwheat}

Buckwheat is a leading cause of anaphylaxis in Korea (39). Various components $(9,16,19$, and $24 \mathrm{kDa})$ are $\mathrm{IgE}$ reactive (40). Among these components, a $16 \mathrm{kDa} 2 \mathrm{~S}$ albumin designated Fag e 2 (41), and a $19 \mathrm{kDa}$ vicilin-like protein designated Fag e 3 (42) are shown to be frequently recognized by IgE from symptomatic allergic patients. However, a $24 \mathrm{kDa}$ protein (Fag e 1), $13 \mathrm{~S}$ globulin seed storage protein 3, and legumin are also recognized by asymptomatic sensitized individuals. Recently, a $3.9 \mathrm{kDa}$ antimicrobial peptide designated Fag e 4 and a $55 \mathrm{kDa}$ vicilin-like protein designated Fag e 5 were characterized (43). However, more studies are necessary since only a small number of patients $(n=7)$ were tested for Fag e $4(5 / 7)$ and Fag e $5(6 / 7)$ allergens. Furthermore, Fag e 4 is homologous to hevein and may possibly be cross-reactive with latex allergens.

\section{Fish}

Chub mackerels, pollacks, largehead hairtails, redlip croakers, flounders, eels, and anchovies are the most commonly consumed fishes in Korea. Interestingly, a very limited number of fish species, such as codfish and mackerel, are currently utilized to diagnose fish allergies in Korea (Table 2). No studies in Korea have been performed into the molecular details of fish allergens. A recent study showed that parvalbumin is the single most potent allergen in Korea, and extensive cross-reactivity among fish species is reported (In press). The high cross-reactivity of parvalbumin allows diagnosis with sibling species. Still, it possible to be sensitized to minor allergens which are not cross-reactive. Therefore, it may be necessary to look into the minor allergens from various fish species in greater detail.

\section{Edible Insects}

The edible insect industry is rapidly growing to overcome food shortages associated with population growth (44). However, more attention should be given to possible allergic adverse reactions after the ingestion of edible insects (45).

The Korean government recently created a code for the edible insect industry. In this code, mealworms, silkworms, Rice grasshoppers, rhinoceros beetles, white-spotted flower chafers, and two-spotted crickets are classified as edible insects (Table 3 ). More studies must be performed on mealworm allergens, which are the most frequently consumed insect worldwide. The most commonly identified IgE reactive molecules are tropomyosin, arginine kinase, paramyosin, chitinase, $\alpha$-amylase, and hexamerin $(46,49-52)$.

As mentioned above, false-positive reactions (asymptomatic sensitization) to silkworm pupa remain an unsolved problem 
TABLE 2 | Comparison of native and imported commercial fish species for clinical use.

\begin{tabular}{|c|c|c|c|c|}
\hline \multirow[t]{2}{*}{ Fish } & \multicolumn{2}{|c|}{ Imported species for clinical use } & \multicolumn{2}{|c|}{ Native species } \\
\hline & Scientific name & Common name & Scientific name & Common name \\
\hline Cod & Gadus morhua & Atlantic cod & Gadus macrocephalus & Pacific cod \\
\hline Mackerel & $\begin{array}{l}\text { Scomber scombus } \\
\text { Scomber japonicus } \\
\text { Scomber australasicus }\end{array}$ & $\begin{array}{l}\text { Atlantic mackerel } \\
\text { Chub mackerel } \\
\text { Japanese/Pacific mackerel }\end{array}$ & Scomber japonicus & Chub mackerel \\
\hline Cutlass & Not available & & Trichiurus lepturus & Largehead hairtail \\
\hline Croaker & Not available & & Larimichthys polyactis & Redlip croaker \\
\hline Anchovy & Engraulis spp. & & Engraulis japonicus & Japanese anchovy \\
\hline
\end{tabular}

TABLE 3 | Edible insects and their potential component allergens.

\begin{tabular}{|c|c|c|c|c|}
\hline \multirow{2}{*}{$\begin{array}{l}\text { Insect } \\
\text { Common name }\end{array}$} & \multicolumn{4}{|c|}{ Component allergen } \\
\hline & Scientific name & Protein & IUIS nomenclature & Reference \\
\hline Silkworm (pupa) & Bombyx mori & $\begin{array}{l}\text { Arginine kinase } \\
27 \text { kDa glycoprotein } \\
\text { Tropomyosin } \\
\text { Paramyosin } \\
\text { Chitinase }\end{array}$ & Bomb m 1 & $\begin{array}{l}\text { Liu et al. (46) } \\
\text { Jeong et al. (47) } \\
\text { Jeong et al. (48) } \\
\text { Zhao et al. (49) } \\
\text { Zhao et al. (49) }\end{array}$ \\
\hline Mealworm (larva) & Tenebrio molitor & $\begin{array}{l}\text { Arginine kinase } \\
\text { Tropomyosin } \\
\alpha \text {-amylase } \\
\text { Paramyosin } \\
\text { Hexamerin/hemocyanin } \\
\text { Myosin } \\
\text { Trypsin } \\
\text { Serine protease }\end{array}$ & & $\begin{array}{l}\text { Verhoeckx et al. (50) } \\
\text { Verhoeckx et al. (50) } \\
\text { Verhoeckx et al. (50) } \\
\text { van Broekhoven et al. (51) } \\
\text { van Broekhoven et al. (51) } \\
\text { van Broekhoven et al. (51) } \\
\text { Verhoeckx et al. (50) } \\
\text { Verhoeckx et al. (50) }\end{array}$ \\
\hline White-spotted flower chafer (larva) & Protaetia brevitarsis seulensis & & & \\
\hline Two-spotted cricket & Gryllus bimaculatus & $\begin{array}{l}\text { Arginine kinase } \\
\text { Hexamerin/hemocyanin }\end{array}$ & & $\begin{array}{l}\text { Srinroch et al. (52) } \\
\text { Srinroch et al. (52) }\end{array}$ \\
\hline Rice grasshopper & Oxya chinensis sinuosa & & & \\
\hline Rhinoceros beetle (larva) & Allomyrina dichotoma & & & \\
\hline
\end{tabular}

for Korean allergic subjects (33). Many studies have focused on cross-reactivity by tropomyosin, mainly from shrimp- and house dust mite-allergic patients, to edible insects. However, silkworm tropomyosin does not have strong allergenicity in Korean patients (48). We identified a $27-\mathrm{kDa}$ glycoprotein as a heat-stable allergen (47) and are working on the characterization of more silkworm pupa allergens.

\section{MISCELLANEOUS ALLERGENS}

\section{Stinging Insects}

Honey bees, bumble bees, yellow jackets, and hornets are the most frequent causes of insect sting anaphylaxes. They are highly cross-reactive with imported stinging insects even though many of them are different species. The Asian needle ant is of particular interest because it is also regarded as an invasive species to western countries. Pac c 3, antigen 5, is the most important allergenic component as found in other wasps (53). However, it is only partially cross-reactive with Ves $\mathrm{v} 5$, a homologous allergen from yellow jackets (54).

\section{ALLERGEN STANDARDIZATION IN KOREA}

In Korea, studies on allergen standardization have been performed with support from the Korean Center for Disease Control and Prevention since 2009 (55, 56). Standardization for the extracts from house dust mites (57), cockroaches (58), and some pollens (mugwort and Japanese hop) (59) was performed and now food allergen standardization is being conducted. Twosite ELISA systems for the quantification of buckwheat allergen Fag e 3 (60) and house dust mite allergen Der f 1 (In press) have been developed. A company with a good manufacturing practice facility for the production of allergen extracts for allergy immunotherapy was established in 2017 (61).

\section{PERSPECTIVES FOR THE DEVELOPMENT OF BETTER ALLERGY DIAGNOSTICS}

Challenge test is the most accurate choice of diagnosis, especially for food allergy. However, physicians should take risks of possible adverse reaction including anaphylaxis. Component-resolved 
diagnosis (CRD) with recombinant or native allergens could be useful for the identification of primary sensitizers and more accurate diagnosis of allergic diseases (62). CRD can discriminate true food allergy from cross-reactive hypersensitivity in food allergy patients, such as pollen food allergy syndrome (63).

Mediator release from effective cells (mast cell and basophil) is dependent not only on the avidity of IgE antibodies to an allergen, but also on the ability to cross-link FceR1 and to compete with blocking antibodies (64). The distance between two different IgE epitopes may have an influence on the immune complex shape and aggregation of FceRI and thus the subsequent activation of basophils (65). Some allergens are not recognized due to its low abundance in the allergenic sources and its extracts. Furthermore, cross-reactive carbohydrate determinant (CCD) often causes false-positive IgE reactions without clinical manifestation (66). Basophil activation test (BAT) could be utilized to overcome these

\section{REFERENCES}

1. Kang MG, Kim MY, Song WJ, Kim S, Jo EJ, Lee SE, et al. Patterns of inhalant allergen sensitization and geographical variation in Korean adults: a multicenter retrospective study. Allergy Asthma Immunol Res. (2017) 9:499508. doi: 10.4168/aair.2017.9.6.499

2. Park HJ Lim HS, Park KH, Lee JH, Park JW, Hong CS. Changes in allergen sensitization over the last 30 years in Korea respiratory allergic patients: a single-center. Allergy Asthma Immunol Res. (2014) 6:434-43. doi: 10.4168/aair.2014.6.5.434

3. Shin JY, Han MJ, Cho C, Kim KR, Ha JC, Oh JW. Allergenic pollen calendar in Korea based on probability distribution models and upto-date observations. Allergy Asthma Immunol Res. (2020) 12:259-73. doi: 10.4168/aair.2020.12.2.259

4. Lee JY, Yang M, Jeong KY, Sim DW, Park JH, Park KH, et al. Characterization of a major allergen from Mongolian oak, Quercus mongolica, a dominant species of oak in Korea. Int Arch Allergy Immunol. (2017) 174:77-85. doi: 10.1159/000481092

5. Jeong KY, Son M, Park JH, Park KH, Park HJ, Lee JH, et al. Cross-reactivity between oak and birch pollens in Korean tree pollinosis. J Korean Med Sci. (2016) 31:1202-7. doi: 10.3346/jkms.2016.31.8.1202

6. Park HS, Nahm DH, Suh CH, Lee SM, Choi SY, Jung KS, et al. Evidence pf hop Japanese pollinosis in Korea: IgE sensitization and identification of allergenic components. J Allergy Clin Immunol. (1997) 100:475-9. doi: 10.1016/s0091-6749(97)70138-6

7. Park JW, Ko SH, Kim CW, Jeoung BJ, Hong CS. Identification and characterization of the major allergen of the Humulus japonicus pollen. Clin Exp Allergy. (1999) 29:1080-6. doi: 10.1046/j.1365-2222.1999. 00615.x

8. Jeong KY, Lee J, Mistrello G, Park KH, Park JW. IgE cross-reactivity between Humulus japonicus and Humulus lupulus. Yonsei Med J. (2018) 59:852-6. doi: 10.3349/ymj.2018.59.7.852

9. Jeong KY, Han IS, Choi SY, Lee JH, Lee JS, Hong CS, et al. Allergenicity of recombinant profilins from Japanese hop, Humulus japonicus. J Investig Allergol Clin Immunol. (2013) 23:345-50.

10. Jang SW, Jeong KY, Yuk JE, Lee J, Park KH, Park JW. Allergen homologues, pathogenesis-related 1, polygalacturonase, and pectin methyl esterase from Japanese hop. Protein Pept Lett. (2021) 28:345-53. doi: 10.2174/0929866527666200813201924

11. Riggins CW, Seigler DS. The genus Artemisia (Asteraceae: Anthemideae) at a continental crossroads: Molecular insights into migrations, disjunctions, and reticulations among Old and New World species from a Beringian perspective. Mol Phylogenet Evol. (2012) 64:471-90. doi: 10.1016/j.ympev.2012. 05.003 limitations. Some Korean scientists carry out BAT for research purpose, but BAT is rarely utilized in clinical fields. Development of more convenient BAT kit may needed for more common use in clinics.

\section{AUTHOR CONTRIBUTIONS}

Conceptualization and writing of the original draft, and final approval by both authors.

\section{FUNDING}

This work was supported by the Medical Device Technology Development Program (20006057, Highly sensitive three-dimensional fluorescent chip for multiple allergy diagnosis) funded by the Ministry of Trade, Industry, and Energy (MOTIE, Korea).

12. Park HS, Hong CS, Choi HJ, Hahm KS. Identification and partial purification of pollen allergens from Artemisia princeps. Yonsei Med J. (1989) 30:346-54. doi: 10.3349/ymj.1989.30.4.346

13. Brandys J, Grimoen A, Nilsen BM, Paulsen BS, Park HS, Hong CS. Crossreactivity between pollen extracts from six Artemisia species. Planta Med. (1993) 59:221-8. doi: 10.1055/s-2006-959656

14. Zhao L, Fu W, Gao B, Liu Y, Wu S, Chen Z, et al. Variation in IgE binding potencies of seven Artemisia species depending on content of major allergens. Clin Transl Allergy. (2020) 10:50. doi: 10.1186/s13601-020-00354-7

15. Jeong KY, Park JW, Hong CS. House dust mite allergy in Korea: the most important inhalant allergen in current and future. Allergy Asthma Immunol Res. (2012) 4:313-25. doi: 10.4168/aair.2012.4.6.313

16. Munhbayarlah S, Park JW, Ko SH, Ree HI, Hong CS. Identification of Tyrophagus putrescentiae allergens and evaluation of cross-reactivity with Dermatophagoides pteronyssinus. Yonsei Med J. (1998) 39:109-15. doi: 10.3349/ymj.1998.39.2.109

17. Son M, Jeong KY, Kim BJ, Kim KJ, Lee JH, Park JW. IgE reactivity to Acarus siro extract in Korean dust mite allergic patients. Exp Appl Acarol. (2014) 63:57-64. doi: 10.1007/s10493-013-9759-6

18. Jeong KY, Lee IY, Yong TS, Lee JH, Kim EJ, Lee JS, et al. Sequence polymorphisms of Der f 1 , Der p 1, Der $\mathrm{f} 2$ and Der p 2 from Korean house dust mite isolates. Exp Appl Acarol. (2012) 58:35-42. doi: 10.1007/s10493-012-9553-x

19. Jeong KY, Lee JY, Son M, Yi MH, Yong TS, Shin JU, et al. Profiles of IgE sensitization to Der f 1, Der f 2, Der f 6, Der f 8, Der f 10, and Der f 20 in Korean house dust mite allergy patients. Allergy Asthma Immunol Res. (2015) 7:483-8. doi: 10.4168/aair.2015.7.5.483

20. Park KH, Lee J, Lee JY, Lee SC, Sim DW, Shin JU, et al. Sensitization to various minor house dust mite allergens is greater in patients with atopic dermatitis than in those with respiratory allergic disease. Clin Exp Allergy. (2018) 48:1050-8. doi: 10.1111/cea.13164

21. Banerjee S, Weber M, Blatt K, Swoboda I, Focke-Tejkl M, Valent $\mathrm{P}$, et al. Conversion of Der $\mathrm{p} 23$, a new major house dust mite allergen, into a hypoallergenic vaccine. J Immunol. (2014) 192:4867-75. doi: 10.4049/jimmunol.1400064

22. Yi MH, Kim CR, Jeong KY, Yong TS. Allergenicity of recombinant Der f 23 and Der p 23 among mite-sensitized patients in Korea. Allergy. (2016) 71:S615.

23. Kim YK, Kim YY. Spider-mite allergy and asthma in fruit growers. Curr Opin Allergy Clin Immunol. (2002) 2:103-7. doi: 10.1097/00130832-200204000-00004

24. Kawai K, Tagoh H, Yoshizaki K, Murakami G, Muraguchi A. Purification and characterization of an allergenic monomeric hemoglobin from a chironomid distributed worldwide, Poypedium nubifer. Int Arch Allergy Immunol. (1996) 110:288-97. doi: 10.1159/000237301 
25. Jeong KY, Yum HY, Lee IY, Ree HI, Hong CS, Kim DS, et al. Molecular cloning and characterization of tropomyosin, a major allergen of Chironomus kiiensis, a dominant species of nonbiting midges in Korea. Clin Diagn Lab Immunol. (2004) 11:320-4. doi: 10.1128/cdli.11.2.320-324.2004

26. Yi MH, Kim JY, Jeong KY, Ree HI, Yong TS. Survey of IgE reactivity to nonbiting midges in Korea and identification of IgE-binding protein. Allergy Asthma Immunol Res. (2019) 11:644-54. doi: 10.4168/aair.2019.11.5.644

27. Vredegoor DW, Willemse T, Chapman MD, Heederik DJ, Krop EJ. Can f 1 levels in hair and homes of different dog breeds: lack of evidence to describe any dog breed as hypoallergenic. J Allergy Clin Immunol. (2012) 130:904-9. doi: 10.1016/j.jaci.2012.05.013

28. Nicholas CE, Wegienka GR, Havstad SL, Zoratti EM, Ownby DR, Johnson CC. Dog allergen levels in homes with hypoallergenic compared with nonhypoallergenic dogs. Am J Rhinol Allergy. (2011) 25:252-6. doi: 10.2500/ajra.2011.25.3606

29. Lindgren S, Belin L, Dreborg S, Einarsson R, Pahlman I. Breedspecific dog dandruff allergen. J Allergy Clin Immunol. (1988) 82:196-204. doi: 10.1016/0091-6749(88)90999-2

30. Polovic N, Waden K, Binmyr J, Hamsten C, Gronneberg R, Palmberg C, et al. Dog saliva - an important source of dog allergens. Allergy. (2013) 68:585-92. doi: 10.1111/all.12130

31. Breitenbuecher C, Belanger JM, Levy K, Mundell P, Fates V, Gershony L, et al. Protein expression and genetic variability of canine Can $\mathrm{f} 1$ in golden and Labrador retriever service dogs. Canine Genet Epidemiol. (2016) 3:3. doi: 10.1186/s40575-016-0031-3

32. Park M, Kim D, Ahn K, Kim J, Han Y. Prevalence of immediate-type food allergy in early childhood in Seoul. Allergy Asthma Immunol Res. (2014) 6:131-6. doi: 10.4168/aair.2014.6.2.131

33. Kim SR, Park HJ, Park KH, Lee JH, Park JW. IgE sensitization patterns to commonly consumed foods determined by skin prick test in Korean adults. $J$ Korean Med Sci. (2016) 31:1197-201. doi: 10.3346/jkms.2016.31.8.1197

34. Lee SC, Kim SR, Park KH, Lee JH, Park JW. Clinical features and culprit food allergens of Korean adult food allergy patients: a cross-sectional single-institute study. Allergy Asthma Immunol Res. (2019) 11:723-35. doi: 10.4168/aair.2019.11.5.723

35. Jeong K, Ye YM, Kim SH, Kim KW, Kim JH, Kwon JW, et al. A multicenter anaphylaxis registry in Korea: Clinical characteristics and acute treatment details from infants to older adults. World Allergy Organ J. (2020) 13:100449. doi: 10.1016/j.waojou.2020.100449

36. Jeong K, Kim J, Ahn K, Lee SY, Min TK, Pyun BY, et al. Age-based causes and clinical characteristics of immediate-type food allergy in Korean children. Allergy Asthma Immunol Res. (2017) 9:423-30. doi: 10.4168/aair.2017.9.5.423

37. Kim MA, Kim DK, Yang HJ, Yoo Y, Ahn Y, Park HS, et al. Pollen-food allergy syndrome in Korean pollinosis patients: a nationwide survey. Allergy Asthma Immunol Res. (2018) 10:648-61. doi: 10.4168/aair.2018.10.6.648

38. Kim M, Ahn Y, Yoo Y, Kim DK, Yang HJ, Park HS, et al. Clinical manifestations and risk factors of anaphylaxis in pollen-food allergy syndrome. Yonsei Med J. (2019) 60:960-8. doi: 10.3349/ymj.2019.60.10.960

39. Lee SY, Ahn K, Kim J, Jang GC, Min TK, Yang HJ, et al. A Multicenter Retrospective Case Study of Anaphylaxis Triggers by Age in Korean Children. Allergy Asthma Immunol Res. (2016) 8:535-40. doi: 10.4168/aair.2016.8.6.535

40. Park JW, Kang DB, Kim CW, Koh SH, Yum HY, Kim KE, et al. Identification and characterization of the major allergens of buckwheat. Allergy. (2000) 55:1035-41. doi: 10.1034/j.1398-9995.2000.00763.x

41. Choi SY, Sohn JH, Lee YW, Lee EK, Hong CS, Park JW. Application of the $16-\mathrm{kDa}$ buckwheat $2 \mathrm{~S}$ storage albumin protein for diagnosis of clinical reactivity. Ann Allergy Asthma Immunol. (2007) 99:254-60. doi: 10.1016/S1081-1206(10)60661-8

42. Choi SY, Sohn JH, Lee YW, Lee EK, Hong CS, Park JW. Characterization of buckwheat $19-\mathrm{kD}$ allergen and its application for diagnosing clinical reactivity. Int Arch Allergy Immunol. (2007) 144:267-74. doi: $10.1159 / 000106315$

43. Geiselhart S, Nagl C, Dubiela P, Pedersen AC, Bublin M, Radauder C, et al. Concomitant sensitization to legumine, Fag e 2 and Fag e 5 predicts buckwheat allergy. Clin Exp Allergy. (2018) 48:217-24. doi: 10.1111/cea.13068

44. van Huis A. Potential of insects as food and feed in assuring food security. Ann Rev Entomol. (2013) 58:563-83. doi: 10.1146/annurev-ento-120811-153704
45. Jeong KY, Park JW. Insect allergen in the dining table. Curr Protein Pept Sci. (2020) 21:159-69. doi: 10.2174/1389203720666190715091951

46. Liu Z, Xia L, Wu Y, Xia Q, Chen J, Roux KH. Identification and characterization of an arginine kinase as a major allergen from silkworm (Bombyx mori) larvae. Int Arch Allergy Immunol. (2009) 50:8-14. doi: $10.1159 / 000210375$

47. Jeong KY, Son M, Lee JY, Park KH, Lee JH, Park JW. Allergenic characterization of $27-\mathrm{kDa}$ glycoprotein, a novel heat-stable allergen, from the pupa of silkworm, Bombyx mori. J Korean Med Sci. (2016) 31:18-24. doi: $10.3346 / \mathrm{jkms} .2016 .31 .1 .18$

48. Jeong KY, Han IS, Lee JY, Park KH, Lee JH, Park JW. Role of tropomyosin in silkworm allergy. Mol Med Rep. (2017) 15:3264-70. doi: $10.3892 / \mathrm{mmr} .2017 .6373$

49. Zhao X, Lin L, Kuang Z, Luo G, Li B. Proteomic and immunological identification of two new allergens from silkworm (Bombyx mori L.) pupae. Cent Eur J Immunol. (2015) 40:30-4. doi: 10.5114/ceji.2015.50830

50. Verhoeckx KC, van Broekhoven S, den Hartog-Jager CF, Gaspari M, de Jong GA, Wichers HJ, et al. House dust mite (Der p 10) and crustacean allergic patients may react to food containing Yellow mealworm proteins. Food Chem Toxicol. (2014) 65:364-73. doi: 10.1016/j.fct.2013.12.049

51. van Broekhoven $S$, Bastiaan-Net $S$, de Jong NW, Wichers HJ. Influence of processing and in vitro digestion on allergic crossreactivity of three mealworm species. Food Chem. (2016) 196:1075-83. doi: 10.1016/j.foodchem.2015.10.033

52. Srinroch C, Srisomsap C, Chokchaichmnankt D, Punyarit P, Phiriyangkul P. Identification of novel allergen in edible insect, Gryllus bimaculatus and its cross-reactivity with Macrobrachium spp. Allergens. Food Chem. (2015) 184:160-6. doi: 10.1016/j.foodchem.2015.03.094

53. Lee EK, Jeong KY, Lyu DP, Lee YW, Sohn JH, Lim KJ, et al. Characterization of the major allergens of Pachycondyla chinensis in ant sting anaphylaxis patients. Clin Exp Allergy. (2009) 39:602-7. doi: 10.1111/j.1365-2222.2008. 03181.x

54. Jeong KY, Yi MH, Son M, Lyu D, Lee JH, Yong TS, et al. IgE reactivity of recombinant Pac c 3 from the Asian needle ant (Pachycondyla chinensis). Int Arch Allergy Immunol. (2016) 169:93-100. doi: 10.1159/000 444364

55. Jeong KY, Hong CS, Lee JS, Park JW. Optimization of allergen standardization. Yonsei Med J. (2011) 52:393-400. doi: 10.3349/ymj.2011. 52.3.393

56. Jeong KY, Lee JH, Kim EJ, Lee JS, Cho SH, Hong SJ, et al. Current status of standardization of inhalant allergen extracts in Korea Allergy Asthma Immunol Res. (2014) 6:196-200. doi: 10.4168/aair.2014. 6.3 .196

57. Jeong KY, Choi SY, Lee JH, Lee IY, Yong TS, Lee JS, et al. Standardization of house dust mite extracts in Korea. Allergy Asthma Immunol Res. (2012) 4:346-50. doi: 10.4168/aair.2012.4.6.346

58. Jeong KY, Choi SY, Lee JH, Lee JS, Yong TS, Hong CS, et al. Preparation and characterization of an extract of German cockroach from a Korean source. Allergy Asthma Immunol Res. (2013) 5:102-5. doi: 10.4168/aair.2013.5.2.102

59. Jeong KY, Son M, Choi SY, Park KH, Hong CS, Lee JH, et al. Standardization of weed pollen extracts, Japanese hop and mugwort, in Korea. Yonsei Med J. (2016) 57:399-406. doi: 10.3349/ymj.2016.57.2.399

60. Jeong KY, Park KH, Lee JH, Park JW. Monoclonal antibodies to recombinant Fag e 3 buckwheat allergen and development of a two-site ELISA for its quantification. Allergy Asthma Immunol Res. (2017) 9:417-22. doi: 10.4168/aair.2017.9.5.417

61. Kim JT, Kim H, Kim SH, Kim DJ, Shin Y, Kim JD, et al. Comparison of allergenic properties among commercially available house dust mite allergen extracts in Korea. Yonsei Med J. (2021) 62:86-90.

62. San Miguel-Rodriguez A, Armentia A, Martin-Armentia S, Martín-Armentia B, Corell A, Lozano-Estevan MC, et al. Component-resolved diagnosis in allergic disease: utility and limitations. Clin Chim Acta. (2019) 489:219-24. doi: 10.1016/j.cca.2018.08.004

63. Park KH, Son YW, Lee SC, Jeong K, Sim DW, Park HJ, et al. Clinical significance of component allergens in Fagales pollen-sensitized peanut allergy in Korea. Allergy Asthma Immunol Res. (2016) 8:505-11. doi: 10.4168/aair.2016.8.6.505 
64. Knol EF. Requirements for effective IgE cross-linking on mast cells and basophils. Mol Nutr Food Res. (2006) 50:620-24. doi: 10.1002/mnfr.200500272

65. Gieras A, Linhart B, Roux KH, Dutta M, Khodoun M, Zafred D, et al. IgE epitope proximity determined immune complex shape and effector cell activation capacity. J Allergy Clin Immunol. (2016) 137:1557-65. doi: 10.1016/j.jaci.2015.08.055

66. van der Veen MJ, van Ree R, Aalberse RC, Akkerdaas J, Koppelman SJ, Jansen $\mathrm{HM}$, et al. Poor biologic activity of cross-reactive IgE directed to carbohydrate determinants of glycoproteins. J Allergy Clin Immunol. (1997) 100:327-34. doi: 10.1016/s0091-6749(97)70245-8
Conflict of Interest: The authors declare that the research was conducted in the absence of any commercial or financial relationships that could be construed as a potential conflict of interest.

Copyright $(02021$ Jeong and Park. This is an open-access article distributed under the terms of the Creative Commons Attribution License (CC BY). The use, distribution or reproduction in other forums is permitted, provided the original author(s) and the copyright owner(s) are credited and that the original publication in this journal is cited, in accordance with accepted academic practice. No use, distribution or reproduction is permitted which does not comply with these terms. 